\title{
PENANAMAN NILAI BUDAYA DAN KARAKTER DENGAN PEMBELAJARAN IPS DALAM SISI ANTROPOLOGI
}

\author{
Rabi Yati \\ Email: 2010128120009@mhs.ulm.ac.id \\ Program Studi Pendidikan IPS Fakultas Keguruan dan Ilmu Pendidikan \\ Universitas Lambung Mangkurat \\ Banjarmasin
}

\begin{abstract}
Abstrak
Salah satu tujuan utama pembelajaran IPS di sekolah adalah untuk membangun peserta didik menjadi warga negara yang baik, dimana salah satu cara untuk mewujudkan tujuan tersebut yaitu dengan penanaman nilai kebudayaan serta pendidikan karakter dalam diri siswa melalui pembelajaran IPS yang berkonsepkan antropologi budaya. Dengan model pembelajaran yang mengandung unsur kebudayaan, pembelajaran tersebut dapat diakukan salah satunya dengan mengintegrasikan nilai-nilai keberagaman budaya lokal ke dalam pembelajaran. Pembangunan karakter saagant diperlukan di dalam diri siswa, dimana dapat kita ketahui bahwasanya pendidikan di negara ini mengalami permasalahan menggenai peananaman karakter pada peserta didik terutama pada usia remaja. Dengan melihat urgensi mengenai penanaman nilai budaya serta karakter siswa tersebut, dibuatlah artikel ini yang membahas mengenai penanaman nilai budaya dan budi pekerti dalam pembelajaran IPS dengan prespektif yang berkonsepkan antropologi budaya. dengan menggunakan metode deskriptif kualitatif artikel ini dibuat berdasarkan fakta dalam kehidupan sosial masyarakat dengan mengacu kepada beberapa literasi dari jurnal maupun artikel penelitian terdahuhulu sehingga diperoleh hasil dan dapat ditarik kesimpulan.
\end{abstract}

\section{PENDAHULUAN}

IPS (Ilmu Pengetahuan Sosial) merupakan suatu ilmu pengetahuan yang telah terintegrasi (gabungan) dari beberapa cabang ilmu-ilmu sosial dan humaniora, seperti, sejarah, ekonomi, geografi, sosiologi, antropologi dan psikologi yang mana tujuan dari pengintegrasian beberapa cabang ilmu tersebut ditujukkan untuk pendidikan dan dijadikan mata pelajaran yang terdapat dalam jenjang sekolah dasar (SD/MI) dan sekolah menengah pertama (SMP/MTs).

Pembelajaran IPS di sekolah bertujuan sebagai alat yang akan membangun peserta didik menjadi warga negara yang baik, yaitu warga negara yang patuh terhadap hukum dan norma yang berlaku, bersikap demokratis serta berpikir kritis. Untuk mencapai tujuan 
tersebut, diperlukan pembelajaran yang berkontekskan kebudayaan dan penanaman nilainilai karakter dalam diri siswa melalui pembelajaran IPS. Yang tentunya dengan pengelolaan pembelajaran yang tepat oleh pendidik serta diolah secara ilmiah dan berdasar pada psikologis yang tepat. Oleh karena itu, dengan melihat dari segi pendidikan karakter dan penanaman nilai dengan melalui pembelajaran IPS yang berkontekskan budaya tersebut, dapat dicapai melalui salah satu bidang ilmu sosial yaitu ilmu antropologi.

Antropologi adalah salah satu cabang ilmu sosial (social science) yang mengkaji mengenai manusia (anthropos). Antropologi ini dapat diartikan sebagi ilmu yang mempelajari/mengkaji mengenai manusia baik secara fisik (biologis) maupun budaya (karya cipta manusia). Dimana antopologi ini secara umum diklasifikasikan menjadi dua bagian yakni antropologi fisik yang mengkaji manusia dari segi biologisnya dan antropologi non-fisik (budaya) yang mengkaji manusia dari kebudayaan atau hasil karyanya (Wahab, A. A., 2014).

Di dalam pembelajaran IPS, peserta didik ditanamkan beberapa nilai-nilai serta pengetahuan yang berdasarkan pada beberapa ilmu-ilmu sosial yang bertujuan untuk membentuk karakter siswa dalam mempersiapkan dirinya dimasa depan untuk menjadi warga negara yang baik (Syaharuddin, 2020). Oleh karena itu ilmu antropologi budaya ini bisa menjadi salah satu alternatif untuk membentuk suatu pembelajaran yang berkontekskan kebudayaan demi membangun nilai-nilai kebudayaan serta budi pekerti yang baik bagi peserta didik.

Dengan melihat urgensi mengenai penanaman nilai budaya serta karakter siswa tersebut, dibuatlah atikrel ini yang membahas mengenai penanaman nilai budaya dan budi pekerti dengan pembelajaran IPS dalam prespektif yang mengacu pada antropologi, terutama antropologi budaya. Artikel ini mengangkat rumusan masalah mengenai hubungan antropologi dengan pendidikan IPS, serta bagaimana pembelajaran IPS yang berkonsepkan antropologi budaya untuk penanaman nilai budaya dan karakter siswa. Dimana dengan menggunakan metode deskriptif kualitatif artikel ini dibua berdasarkan fakta dalam kehidupan sosial masyarakat dengan mengacu kepada beberapa literasi dari jurnal maupun artikel penelitian terdahuhulu sehingga diperoleh hasil dan dapat ditarik kesimpulan. 


\section{METODE}

Artikel ini dibuat dengan menggunakan metode deskriptif kualitatif. Adalah suatu metode yang membantu dalam hal penggambaran mengenai suatu persoalan dengan pendeskripsian suatu fenomena serta pemecahan masalah berdasarkan fakta yang ada dan bertumpu pada penelitian-penelitian terdahulu. Metode ini dilakukan dengan mendeskripsikan atau menjelaskan mengenai fakta-fakta yang kemudian dituangkan ke dalam bentuk kalimat. Penggunaan latar alamiah yang telah menjadi ciri khas penelitian kualitatif, dengan pemanfaatan metode deskriptif (Jumriani, 2020). Sumber-sumber data yang terdapat dalam artikel ini ditulis berdasarkan fakta yang terdapat pada jurnal-jurnal dan artikel-artikel yang terjamin ke absahannya. Dan untuk pengumpulan data-data pendukung didapat melalui beberapa studi literarur dari buku-buku, modul, serta artikel maupun jurnal-jurnal lain yang berhubungan mengenai penulisan artikel ini. Kemudian hasil dari studi literatur tersebut dapat diolah berdasarkan rumusan masalah yang di diangkat dalam artikel ini. setekah mendapatkan hasil serta pemecahan masalah dari rumusan masalah tersebut lalu dituangkan dan di definisikan ke dalam artikel ini berdasarkan fakta yang didapat sehingga dapat ditarik kesimpulannya.

\section{HASIL DAN PEMBAHASAN}

\section{Hubungan Antropologi Dengan Pendidikan IPS}

Ilmu Pengetahuan Sosial (IPS) Menurut NCSS (National Council for Social Studies) adalah sebuah mata pelajaran yang terpadu atau terintegrasi sedemian rupa, merupukan kumpulan ilmu-ilmu sosial dan humaniora yang memadukan beberapa disiplin ilmu tersebut secara sistematis seperti geografi, sejarah, ekonomi, sosiologi, antropologi, psikologi dan lain-lain. IPS sebagai salah satu mata pelajaran wajib di dalam kurikulum pendidikan, dimana mata pelajaran ini terdapat pada jenjang SD/MI dan SMP/MTS (Mutiani, M. 2020). IPS dalam pembahasannya mengkaji mengenai gejal-gejala seerta masalah sosial yang ada di dalam masyarakat, dengan melihat dari beberapa presfektif ilmu-ilmu sosial dan humaniora yang terpadu didalamnya, dimana objek kajiannya adalah manusia. Dan dari banyaknya disiplin ilmu yang terintegrasi di dalam IPS salah satunya ada antropologi, terutama antropologi budaya yang mengkaji mengenai manusia dan kebudayaannya. 
Antropologi adalah sebuah cabang ilmu sosial dan juga merupakan salah satu cabang ilmu yang juga terkandung di dalam IPS. Antropologi merupakan ilmu yang terintegrasi dari beberapa ilmu dan mempelajari mengenai manusia sebagai makhluk biososial. Dimana secara harfiah antropologi berasal dari bahasa Yunani yakni antropos yang berarti manusa dan logos yang berarti ilmu, dimana dengan pengertian tersebut antropologi dapat diartikan sebagai ilmu yang mengkaji tentang manusia. Ilmu ini permulaan dikembangkan pada abad-19 $\mathrm{M}$ dan berkembang hingga sekarang sebagai salah satu disiplin ilmu yang mengkaji mengenai manusia secara fisik atau biologis amupun mengkaji manusia dalam segi budayanya.

Manusia dalam sehari-hari tidak lepas dari kehidupannya sebagai mahluk sosial dan sebagai anggota masyarakat. Dalam konteks sosialnya, manusia meliputi berbagai aspek, termasuk kebudayaan. Dimana kebudayaan ini ada seiring dengan aktivitas manusia dalam memenuhi kebutuhannya serta aktivitas sehari-hari yang kemudian akan menciptakan suatu kebiasaan yang dilakukan daalam waktu yang berulang hingga terciptalah suatu kebudayaan. yang mana apabila aktivitas tersebut dilakukan oleh sekelompok orang dalam suatu wilayah atau lingkungan akan disebut sebagai kebudayaan masyarakat. Dalam konseop kebudayaan inilah antropologi budaya mengkaji manusia sebagai makhluk yang berbudaya.

\section{Penanaman Nilai Budaya \& Budi Pekerti Dengan Sisi Antropologi}

Dalam antropologi manusia dianggap sebagai makhluk sosial yang tidak terlepas dari yang namanya kebudayaan. Dimana salah satu kajian ilmu antropologi adalah manusia dengan kebudayaan atau karyanya. Kebudayaan telah menjadi suatu identitas yang melekat dalam kehidupan manusia pada suatu kelompok, wilayah maupun negara. Pada dasarnya kebudayaan adalah hasil karya cipta manusia yang tidak terlepas dari beberapa pemikiranpemikiran manusia dalam beberapa aspek kehidupan untuk mempermudah jalannya kehidupan dalam kesehariannya.

Budaya bukan hanya terbatas pada kesenian semata, namun budaya itu begitu luas dan beragam bentuknya. Unsur unsur kebudayaan menurut Koetjiningrat (1990:2003-204) di dunia ada tujuh, yakni bahasa, organisasi sosial, sistem pengetahuan, sistem mata pencaharian, sistem peralatan hidup dan teknologi, kesenian dan sistem relegi. Hal ini sesuai dengan wujud dari kebudayaan itu sendiri yang dapat berupa ide atau gagasan, norna-norma sosial dan hasil karya manusia bai dalam hal aktifitas maupun kebendaan. 
Setiap wilayah baik itu daerah maupun negara memiliki budayanya masing-masing yang telah menjadi suatu ciri khas tersendiri. Bahkan budaya ini telah menjadi identitas nasional bagi suatu negara yang membedakannya dari negara yang satu dengan negara yang lain mulai dari bahasa, norma-norma atau pengaturan hingga kesenian.

Dalam kehidupan sosial masyarakat, diperlukan sebuah sistem nilai budaya bagi masyarakat sebagai tata cara dalam bertingkah laku dalam kesehariannya agar tidak bertentangan dengan nilai dan norma yang ada dan berlaku di dalam masyarakat. Oleh karena itu, nilai budaya sangat diperlukan dalam kehidupan sehari-hari sebagai pedoman manusia dalam bertingkah laku. Nilai budaya ini dapat ditanamkan sedari dini kepada peserta didik melalui pengajaran IPS di sekolah yang mana melalui pembelajaran tersenut diharapkan nilai-nilai serta sikap yang baik dapat ditanamkan dengan baik oleh peserta didik.

Nilai budaya menurut Koentjaningrat merupakan suatu sistem nilai- budaya yang terdiri dari beberapa konsep atau gagasan-gagasan yang hidup dalam pemikiran sebagian besar dari warga masyarakat, mengenai hal-hal yang harus mereka anggap amat berharga atau bernilai dalam hidup (Koentjaraningrat, 1974). Sehingga dengan itu nilai budaya dapat dikatakan sebagai suatu nilai yang menjadi pedoman bagi masyarakat dalam bertingkah laku yang ada dalam pemikiran masyarakat, yang mendasari adanya norma, hukum serta aturan-aturan yang berlaku dalam masyarakat. Jadi segala tingkah laku, sikap, pengaturan, hukum maupun norma dalam masyarakat itu didasari oleh nilai budaya yang bersumber pada sistem nilai budaya (Kistanto, 2015).

Sistem nilai budaya ini menjadi pedoman tertinggi manusia dalam kehidupan bermasyaralat, yang bukan hanya berpengaruh dalam hal tingkah laku maupun sikap seseorang melainkan juga menjadi dasar dalam mencapai sebuah tujuan hidup. Oleh karena itu, dalam pendidikan IPS diperlukan penanaman nilai-nilai budaya melalui model pembelajaran yang mengandung unsur kebudayaan untuk membentuk karakter pada peserta didik yang dilandasi moral baik yang diperoleh dari nilai-nilai budaya. Model pembelajaran tersebut dapat diakukan salahsatunya yaitu dengan mengintegrasikan nilainilai keberagaman pada budaya lokal ke dalam pembelajaran IPS.

Belajar dari kebudayaan lokal dari negara kita sendiri, Indonesia merupakan suatu negara yang kaya akan keberagaman baik itu suku, ras, bahasa dan agama namun dari keberagamnnya tersebut indonegia disatukan dalam satu kesatuan yang sesuai dengan 
semboyan negara kita yaitu Bhineka Tunggal Ika yang artinya berbeda-beda tetapi tetap satu jua. Kebudayaan di indonesia begitu beragam bahkan dalam satu pulau setiap daerahnya memiliki kebudayaan yang berbeda-beda di setiap wilayahnya. Melalui keberagaman budaya lokal inilah yang dapat digunakan sebagai model pembelajaran dimana nilai-nilai dari kebudayaan tersebut dimasukkan ke dalam pembelajaran melalui pendekatan nilai dengan memfokuskan terhadap keaktifan peserta didik dalam menganalisis, menghargai dan bertindak, sehingga nilai-nilai budaya yang terdapat di dalam kebudayaan tersebut akan membangun serta menumbuhkan nilai karakter yang dibutuhkan siswa.

Pembangunan karakter saagant diperlukan di dalam diri siswa, dimana dapat dita hetahui bahwasanya pendidikan di negara ini mengalami permasalahan menggenai peananaman karakter pada peserta didik terutama pada usia remaja, yang mana pada usia inilah yang rentan akan krisis nilai karakter di dalam dirinya. Oleh karena itu, dengan pembelajaran IPS yang bermodelkan antropologi budaya diharapkan bisa membangun karakter siswa melalui nilai-nilai budaya yang terkandung di dalam kebudayaan lokal di negara Indonesia. Selain itu model pembelajaran ini dapat mencapai tujuan dari Pendidikan IPS itu sendiri yakni membangun peserta didik menjadi warga negara yang baik, yang salah satunnya yaitu dengan penanaman nilai-nilai budaya dalam diri siswa.

\section{SIMPULAN}

IPS (Ilmu Pengetahuan Sosial) merupakan suatu ilmu pengetahuan yang telah terintegrasi sedemikian rupa dari beberapa cabang ilmu-ilmu sosial dan humaniora yang ditujukkan untuk pendidikan. Pembelajaran IPS bertujuan untuk membangun peserta didik menjadi warga negara yang baik, yaitu warga negara yang patuh terhadap hukum dan norma yang berlaku, bersikap demokratis serta berpikir kritis.

Untuk mencapai tujuan tersebut, diperlukan adanya penanaman nilai budaya serta karakter dalam diri siswa. Hal ini bisa didapat dengan melalui penyusunan pembelajaran IPS yang bermodelkan antropologi budaya, dengan model pembelajaran tersebut, diharapkan pembelajaran IPS dapat membangun karakter siswa melalui nilai-nilai budaya yang terkandung di dalam kebudayaan-kebudayaan lokal di negara Indonesia.

Belajar dari kebudayaan lokal dari negara kita sendiri, Indonesia merupakan suatu negara yang kaya akan keberagaman baik itu suku, ras, bahasa dan agama. Melalui 
keberagaman budaya lokal inilah yang dapat digunakan sebagai model pembelajaran dimana nilai-nilai dari kebudayaan tersebut dimasukkan ke dalam pembelajaran melalui pendekatan nilai dengan memfokuskan terhadap keaktifan peserta didik dalam menganalisis, menghargai dan bertindak, sehingga nilai-nilai budaya yang terdapat di dalam kebudayaan tersebut akan membangun serta menumbuhkan nilai karakter yang dibutuhkan siswa.

\section{REFERENSI}

Abbas, E. W. (2021, May). Banua Anyar Culinary Tourism Area: Study Of Economic Activities As A Learning Resource on Social Studies. In IOP Conference Series: Earth and Environmental Science (Vol. 747, No. 1, p. 012019). IOP Publishing.

Abbas, E. W. (2019). Building Nation Character Through Education: Proceeding International Seminar on Character Education.

Affandy, S. (2017). Penanaman Nilai-Nilai Kearifan Lokal dalam Meningkatkan Perilaku Keberagamaan Peserta Didik. Atthulab: Islamic Religion Teaching and Learning Journal, 2(2), 201-225.

Ahya, R. R., Syaharuddin, S., \& Rahman, A. M. (2020). The Caring Attitudes for Environment of Lanting Householders as a Learning Resource on Social Studies. The Innovation of Social Studies Journal, 2(1), 66-74.

Handy, M. R. N., Mutiani, M., Putra, M. A. H., \& Jumriani, J. (2020). The Religious Values in Tradition of Batahlil in Banjar Pahuluan Community. The Kalimantan Social Studies Journal, 2(1), 39-47.

Hetarion, B. D., Hetarion, Y., \& Makaruku, V. (2020). Implementasi Pendidikan Karakter Berbasis Kearifan Lokal Cuci Negeri dalam Pembelajaran IPS. JTP-Jurnal Teknologi Pendidikan, 22(1), 1-12.

Ilmiyannor, M., \& Mi'rajiatinnor, D. (2021, February). Strengthening Environmental Care Attitudes Through Social Wisdom-Based Social Studies Learning. In The 2nd International Conference on Social Sciences Education (ICSSE 2020) (pp. 65-69). Atlantis Press.

Kistanto, N. H. (2015). Tentang konsep kebudayaan. Sabda: Jurnal Kajian Kebudayaan, 10(2). 
Lestari, J. A., Abbas, E. W., \& Mutiani, M. (2020). Production Activities of Kampung Purun Banjarbaru as a Learning Resource on Social Studies. The Innovation of Social Studies Journal, 1(2), 139-149.

Parni, P. (2017). PENERAPAN PENDIDIKAN KARAKTER DALAM PEMBELAJARAN IPS SD/MI. Jurnal Alwatzikhoebillah: Kajian Islam, Pendidikan, Ekonomi, Humaniora, 3(6), 184-195.

Puspitasari, R. (2016). Penanaman nilai karakter peduli lingkungan dalam muatan environmental education pada Pembelajaran IPS di MI Darul Hikam Kota Cirebon. Al Ibtida: Jurnal Pendidikan Guru MI, 3(1).

Rahayu, R., Abbas, E. W., \& Jumriani, J. (2021). Social Studies Lesson Planning for Children with Intellectual Disabilities in the Pembina State Special School of South Kalimantan Province. The Kalimantan Social Studies Journal, 2(2), 160-169.

Siti, P. Y. (2020). MEMPERKUAT PENDIDIKAN KARAKTER NASIONALISME MELALUI PEMBELAJARAN IPS. In PROSIDING SEMINAR INTERNASIONAL KOLOKIUM 2020.

Supriatna, E. (2012). Transformasi pembelajaran sejarah berbasis religi dan budaya untuk menumbuhkan karajumberianiter siswa. ATIKAN, 2(1).

Syaharuddin, S., \& Mutiani, M. (2020). Strategi Pembelajaran IPS: Konsep dan Aplikasi.

Syaharuddin, S., Samihati, M., \& Jumriani, J. (2020). AKTUALISASI SIKAP PEDULI LINGKUNGAN MELALUI AKTIVITAS PENGELOLAAN SAMPAH. Jurnal Socius, 9(2), 193-203.

Wahyu, W. (2020). Kearifan Lokal dan Pendidikan IPS.

Wahab, A. A. (2014). Konsep Dasar IPS. Tanggerang selatan: Universitas terbuka.

Yuniarti, D., Subiyakto, B., \& Putra, M. A. H. (2020). Economic Activities in Kuin Floating Market as a Learning Resource on Social Studies. The Kalimantan Social Studies Journal, 1(2), 130-140. 